\title{
PENGEMBANGAN SISTEM INFORMASI PEMASARAN PADA CV. RUMAH VERA
}

\author{
Sugiarto Hartono \\ Computerized Accounting Department, School of Information Systems, Binus University \\ Jl. K. H. Syahdan No. 9, Palmerah, Jakarta Barat 11480 \\ shartono@binus.edu
}

\begin{abstract}
Evolving information technology can make business processes, which are carried out traditionally, transformed through the application of information technology that is useful for companies. Effective information systems design, should be used and provide a positive influence for the benefit of the organization. $C V$. Rumah Vera is a company that is engaged in the business of selling and marketing the property. The company began to realize that the implementation of information systems is very important in the development of its business. Rumah Vera requires a system that utilizes information technology, which can record all business transactions related to the marketing information system. Design methodology used is Agile methodology with object-oriented approach.
\end{abstract}

Keywords: system development, marketing system

\begin{abstract}
ABSTRAK
Teknologi informasi yang berkembang dapat membuat proses bisnis yang dilakukan secara tradisional ditransformasikan melalui penerapan teknologi informasi, yang berguna bagi perusahaan. Desain sistem informasi yang efektif harus dapat digunakan dan memberikan pengaruh positif bagi kepentingan organisasi. CV. Rumah Vera merupakan suatu perusahaan yang begerak dalam bidang usaha penjualan dan pemasaran property rumah. Perusahaan ini mulai menyadari bahwa penerapan sistem informasi sangat penting dalam upaya pengembangan bisnisnya. Rumah Vera membutuhkan sebuah sistem yang memanfaatkan teknologi informasi yang dapat mencatat seluruh transaksi bisnis yang berkaitan dengan sistem informasi pemasaran. Metodologi perancangan yang digunakan adalah metodologi Agile dengan pendekatan object oriented. Simpulan penulisan ini adalah keberadaan sistem informasi pemasaran yang terkomputerisasi membuat seluruh data tersimpan dalam database dan ter-update secara real time.
\end{abstract}

Kata kunci: pengembangan sistem, sistem pemasaran 


\section{PENDAHULUAN}

Di era globalisasi sekarang ini, banyak perusahaan berlomba-lomba dalam meraih pasar yang semakin terbuka luas. Segala strategi dan cara dilakukan untuk mencapai tujuan dan profit yang di inginkan. Sebuah perusahaan harus mampu mengikuti perubahan yang terjadi, baik di dalam maupun di luar perusahaan. Namun banyak perusahaan yang cenderung masih berpikiran tradisional dan tidak mengharapkan adanya perubahan. Tentunya perusahaan akan menemui banyak kesulitan dalam menghadapi persaingan pasar bebas yang membutuhkan daya saing dan kreativitas. Berkembangnya teknologi informasi yang ada dapat membuat proses bisnis yang dilakukan secara tradisional ditransformasikan melalui penerapan teknologi informasi yang berguna bagi perusahaan. Sudah banyak sekali perusahaan-perusahaan yang bertransformasi menjadi perusahaan maju berlandaskan teknologi informasi yang terintegrasi secara baik.

Menurut Satzinger, Jackson, \& Burd (2005), sistem informasi adalah sekumpulan komponenkomponen yang saling berhubungan yang mengumpulkan, memproses, menyimpan, dan menghasilkan output yang menjadi informasi dalam menyelesaikan sebuah pekerjaan. Di dalam perusahaan sangat dibutuhkan penerapan sistem informasi berbasis komputer di dalam menjalankan proses bisnisnya untuk dapat meningkatkan daya saing serta meningkatkan produktivitas karyawan. Dilihat dari segi kualitatif, penggunaan sistem informasi dan teknologi informasi dapat meningkatkan efektivitas proses bisnis perusahaan dan meningkatkan kepuasan pelanggan. Dan dilihat dari segi kuantitatif, penggunaan SI dan TI dapat meningkatkan keuntungan ekonomi bagi perusahaan tersebut. Desain sistem informasi yang efektif harus dapat digunakan dan memberikan pengaruh positif bagi kepentingan organisasi (Markus, Majchrzak, \& Gasser, 2003).

Penggunaan database juga dapat memberikan keuntungan bagi perusahaan. Connolly dan Begg (2005), mengkaji keuntungan penggunaan Database Management System antara lain dapat mengontrol redundansi data atau data yang berlipat ganda, menjaga konsistensi data, dapat berbagi data antar pengguna sistem, meningkatkan integritas data, meningkatkan keamanan, penegakan standar, meningkatkan aksesibilitas data dan responsive, peningkatan produktivitas, meningkatkan pemeliharaan melalui independensi data, meningkatkan konkurensi, peningkatan cadangan dan pemulihan layanan.

Objek penelitian yang digunakan adalah CV. Rumah Vera. CV. Rumah Vera merupakan suatu perusahaan yang begerak dalam bidang usaha penjualan dan pemasaran property rumah. Menurut Kotler (2004), pemasaran adalah sebuah proses sosial dan manajerial di mana individu-individu dan kelompok-kelompok mendapatkan apa yang mereka butuhkan dan inginkan melalui penciptaan, penawaran dan pertukaran produk-produk atau value dengan pihak lainnya. Definisi ini berdasarkan pada beberapa konsep-konsep inti, seperti: kebutuhan, keinginan, dan permintaan produk-produk (barang, servis, dan ide), value, biaya, dan kepuasan, pertukaran dan transaksi, hubungan dan networks, pasar dan para pemasar, serta prospek. Menurut Kotler (2006), penjualan merupakan sebuah proses dimana kebutuhan pembeli dan kebutuhan penjual dipenuhi, melalui antar pertukaran informasi dan kepentingan.

Perusahaan ini dalam melakukan penjualan rumah yang dipasarkan masih menggunakan sistem manual dengan menggunakan banyak kertas yang dipakai sebagai media pencatatan dan pelaksanaan proses bisnis, sehingga kurang efektif dan efisien. Kendala lain yang dihadapi oleh CV. Rumah Vera adalah pengaturan data para pembeli yang tidak tersusun secara rapi, serta proses penjualan dan pengecekan stok rumah yang masih menyita banyak waktu. Tujuan dari penelitian ini adalah melakukan analisis persyaratan pengguna dan persyaratan sistem serta membuat sebuah desain sistem informasi dari proses bisnis pemasaran di CV. Rumah Vera. Manfaat penelitian ini adalah menghasilkan sebuah rancangan sistem yang dapat menghasilkan laporan yang dapat digunakan oleh pihak manajemen untuk keperluan strategis. 


\section{METODE}

Metode yang digunakan dalam penelitian ini adalah Metode Pengumpulan Data dan Metode Pengembangan Sistem Informasi. Metode Pengumpulan Data dilakukan melalui (1) Observasi; melakukan survei lapangan, pengamatan pada CV. Rumah Vera untuk mendapatkan data dan informasi yang dibutuhkan untuk merancang sistem informasi. (2) Wawancara; melakukan sesi tanya jawab kepada pihak CV. Rumah Vera untuk mengetahui proses bisnis yang berjalan, melakukan analisis masalah, serta untuk mengidentifikasi kebutuhan user. (3) Studi Kepustakaan; mengumpulkan informasi yang berasal dari buku dan jurnal yang mendukung, berhubungan, serta berguna dalam penelitian ini.

Metode Pengembangan Sistem Informasi dilaksanakan dengan melakukan analisis sistem pada data-data yang diperoleh dengan menggunakan metode Agile berorientasi objek. Agile methodology merupakan salah satu metodologi untuk melakukan problem solving dan membutuhkan adanya peran serta partisipasi seluruh stakeholder (Forster \& Brocco, 2008). Stakeholder dalam hal ini adalah pihak pengembang sistem dan pihak perusahaan CV. Rumah Vera. Keseluruhan stakeholder tersebut melakukan brainstorming untuk menganalisis sistem yang akan dikembangkan. Analisis sistem dalam penelitian ini menggunakan pendekatan Object-Oriented, di mana untuk penggambaran model analisis menggunakan notasi grafis UML (Satzinger, 2012). Untuk merancang tampilan antarmuka pengguna menggunakan prinsip perancangan user interface (Dennis, Wixom, \& Roth, 2013).

\section{HASIL DAN PEMBAHASAN}

Proses bisnis pemasaran berjalan di CV. Rumah Vera melalui kegiatan marketing menyebarkan brosur penjualan rumah, kemudian calon pembeli yang tertarik akan menghubungi CV. Rumah Vera melalui telepon atau datang langsung ke kantor CV. Rumah Vera. Calon pembeli harus mengisi buku tamu yang disediakan dengan data yang lengkap dan jelas. Buku tamu ini berfungsi sebagai record untuk mengetahui siapa saja calon pembeli yang datang. Buku tamu yang digunakan masih berupa buku yang harus diisi oleh pembeli secara manual. Marketing akan mengajak calon pembeli untuk survei melihat rumah yang ingin dibeli.

Calon pembeli berminat diwajibkan membayar booking fee sebagai tanda jadi. Besaran nilai booking fee ini sebesar Rp.500.000,00 dan calon pembeli akan mendapatkan bukti pemesanan berupa kuitansi booking dan Surat Pemesanan Rumah (SPR). Setelah melakukan booking fee, 1-2 hari kemudian calon pembeli akan dihubungi oleh petugas marketing guna mengkonfirmasi data-data dan membantu pembeli dalam melengkapi persyaratan dan data penunjang yang dibutuhkan. Dan selambat-lambatnya dalam waktu dua minggu dari tanggal booking, semua berkas dan kelengkapan persyaratan KPR tersebut sudah harus diserahkan.

Syarat bagi calon pembeli yang ingin membeli rumah dengan KPR adalah belum memiliki rumah. Marketing akan membawa SPR dan berkas-berkas persyaratan pembeli ke developer. Kemudian, berkas tersebut dan SPR akan diberikan developer ke bank. Lalu bank akan mengundang pembeli untuk mengikuti proses interview (wawancara), sebagai prosedur pengajuan kredit. Undangan wawancara diberikan kepada calon pembeli maksimal dua hari sebelum diselenggarakan.

Setelah calon pembeli dinilai layak untuk menerima Fasilitas pinjaman KPR, maka pihak bank akan menerbitkan SP3K (Surat Penegasan Persetujuan Pemberian Kredit), di mana di dalam SP3K ini akan muncul jumlah kredit yang disetujui, jangka waktu kredit, nilai angsuran, termasuk biaya yang timbul dari proses pengajuan KPR. Setelah SP3K, selanjutnya pembeli harus melunasi uang muka, hook, biaya strategis dan lain-lain. Sesuai dengan ketentuan dalam pricelist dan harga jual pada brosur, pembeli mempunyai kewajiban melunasi uang muka pembelian rumah tersebut beserta biaya-biaya 
lain (Biaya Proses KPR, Biaya Strategis, dan sebagainya) sesuai dengan jadwal pembayaran yang telah pembeli sepakati dalam Surat Pemesanan Rumah (SPR) dengan pihak bank.

Saat ini sistem yang digunakan CV. Rumah Vera dalam seperti pendaftaran marketing dan pencatatan komisi marketing masih menggunakan kertas. Staf marketing akan mendapatkan komisi setiap bulan. Besarnya komisi marketing sebesar Rp350.000,00 untuk setiap rumah yang berhasil mereka jual. Direktur CV. Rumah Vera melakukan pengecekan stok rumah menggunakan kertas, dengan menerima denah perumahan serta blok-blok yang ada dari pihak developer. Admin akan menandai rumah-rumah yang sudah terjual dengan menamai setiap rumah di dalam gambar tersebut dengan nama pembelinya. Pada proses ini admin akan menginput daftar rumah yang didapatkan dari para developer yang bekerja sama dengan perusahaan.

Masalah yang ditemui pada proses bisnis berjalan yaitu masih mengandalkan banyaknya kertas yang berupa form dalam mendata pembeli, sehingga menimbulkan banyaknya waktu yang terbuang untuk mengisi dan memindahkan data penjualan. Dalam melakukan manajemen marketing Rumah Vera mengalami banyak kesulitan dari menentukan komisi yang akan diberikan kepada marketing dan pendataan pada saat pendaftaran marketing karena pencatatannya hanya berdasarkan kertas, banyak sekali human error yang sering terjadi dari hilangnya kertas tersebut sampai kecurangan dari karyawan itu sendiri. CV. RumahVera masih menggunakan cara manual dengan nama mencatat nama rumah mana yang belum terjual ataupun yang sudah terjual.

Dari hasil temuan masalah pada proses bisnis berjalan CV. Rumah Vera, maka diusulkan sebuah proses bisnis yang dapat mengatasi permasalahan yang dihadapi CV. Rumah Vera. Berikut adalah proses bisnis yang diusulkan : 


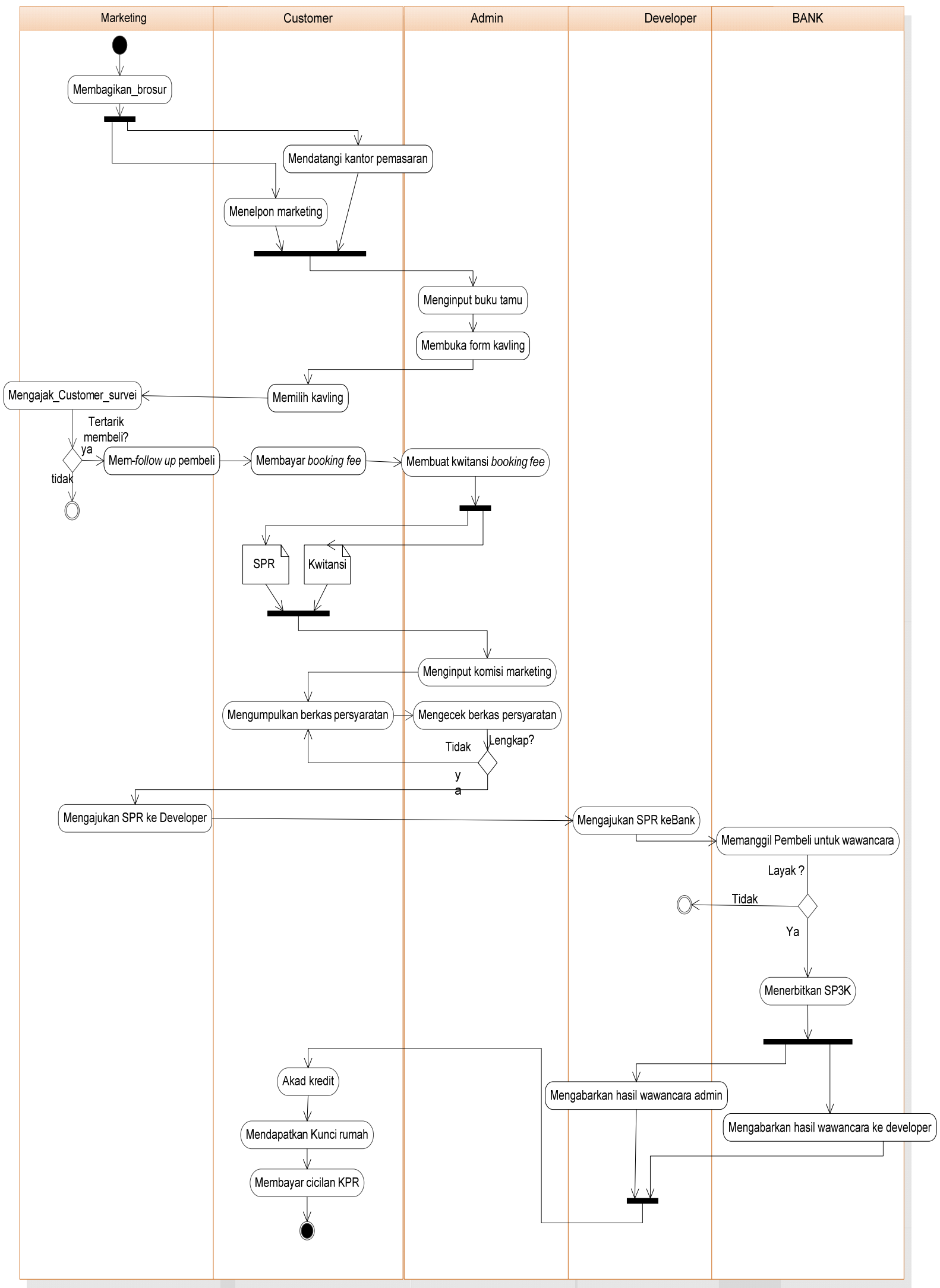

Gambar 1 Activity Diagram Proses Bisnis yang Diusulkan 


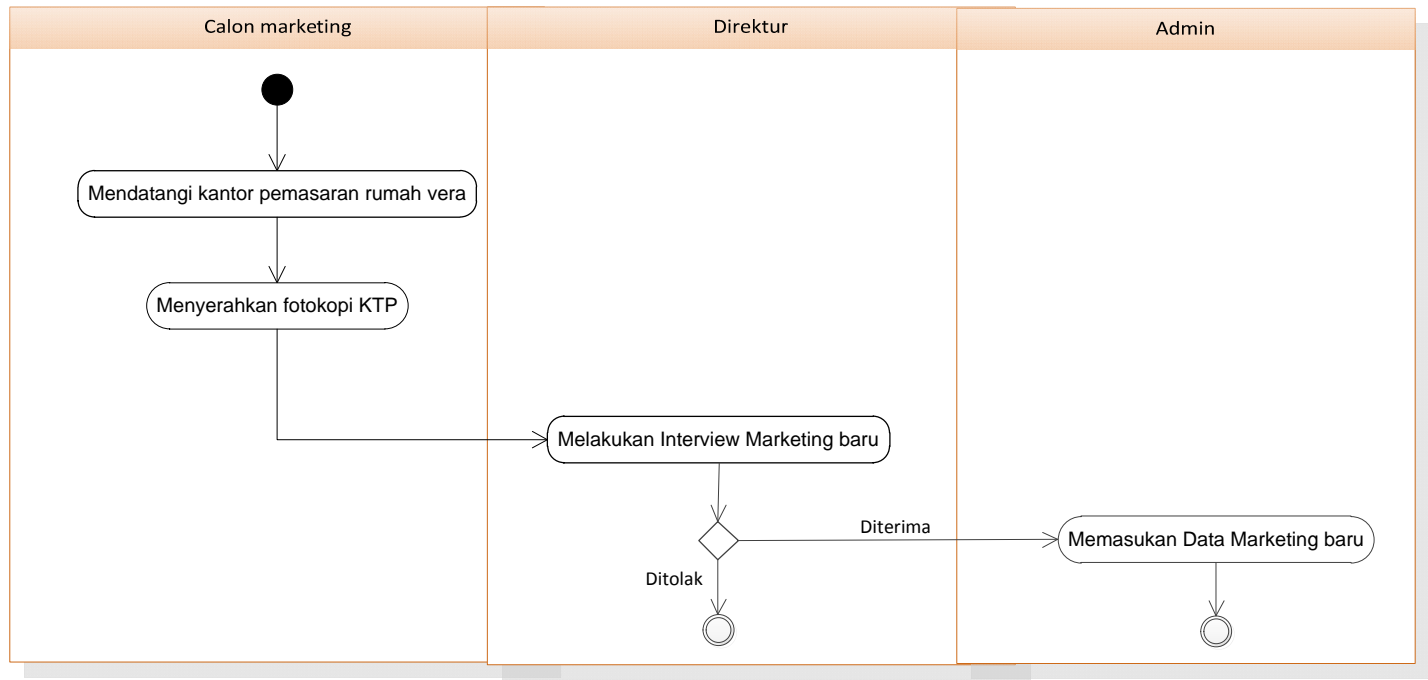

Gambar 1 Activity Diagram Proses Bisnis yang Diusulkan (Lanjutan)

Adapun persyaratan user dari pihak CV. Rumah Vera adalah sebagai berikut :

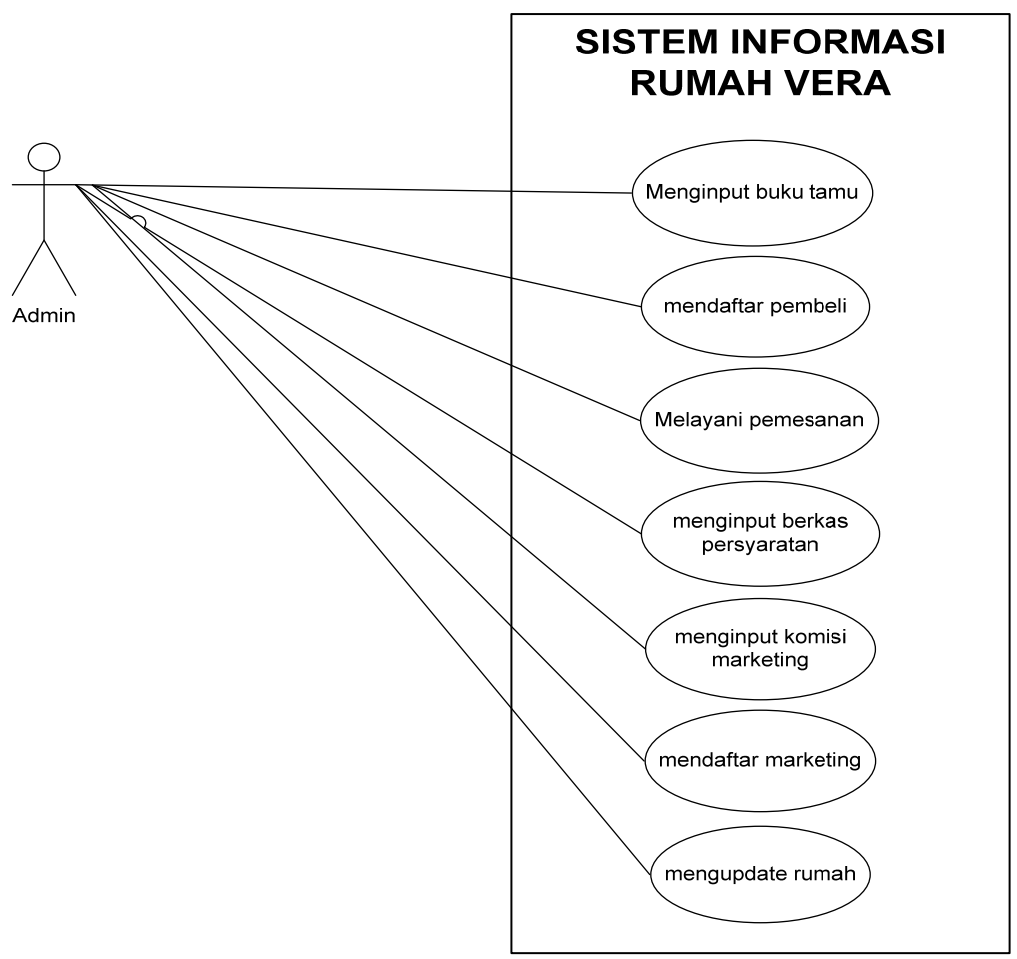

Gambar 2 Usecase Diagram Sistem Informasi Marketing CV. Rumah Vera 
Pekerjaan admin akan dimudahkan dalam menjalankan tugasnya dengan menggunakan aplikasi yang dirancang untuk proses bisnis CV Rumah Vera. Dengan menggunakan aplikasi ini, admin akan mampu mendata calon pembeli melalui form pembeli dengan penyimpanan datanya di dalam database, sehingga penyimpanan data dapat dilakukan secara real time. Selain itu, admin dapat dengan mudah mencatat komisi marketing berdasarkan pesanan pembelian rumah yang sudah tercatat datanya, jadi akan dengan mudah melihat marketing mana saja yang sudah mendapatkan komisi.

Spesifikasi komputer yang dibutuhkan untuk implementasi sistem ini adalah sebagai berikut :

Tabel 1 Spesifikasi Komputer

\begin{tabular}{lll}
\hline SPARE-PART & \multicolumn{2}{l}{ DESKRIPSI } \\
\hline Intel LGA 1155 & 1 & Intel BG 620 Dual Core (Box) (2.6Ghz/C3Mb) intel LGA 1155 \\
\hline MB. Intel LGA & 1 & Asus P5G41TMLX \\
\hline Memory DDR3 & 1 & V-GEN 2Gb PC 10600 \\
\hline Harddisk 3.5Inch & 1 & WDC SATA III Blue 500Gb 16Mb 3.5Inch Int 3,5 Inch \\
\hline Casing Value & 1 & Value Simbadda Sim X 622/628/653/655 380W 2 USB Slim \\
\hline Optical Drive & 1 & Samsung DVDRW SATA OEM Internal \\
\hline LCD 19inch Kebawah & 1 & AOC 18.5 Inch N950SW Size 18 inch \\
\hline Keyboard & 1 & GENIUS KB Slimstar 120 PS2 Keyboard \\
\hline Mouse & 1 & Power Logic 2GO Zero Flek Mouse
\end{tabular}

Sistem Informasi CV.Rumah Vera akan digunakan pola Centralized karena CV. Rumah Vera hanya terfokus di satu tempat. Software yang digunakan oleh CV. Rumah Vera adalah Single Tier. Keuntungan dari aplikasi Single Tier adalah kesederhanaan, performance yang tinggi, dan mendukung integritas data.

Bentuk class diagram dari sistem yang diusulkan: 


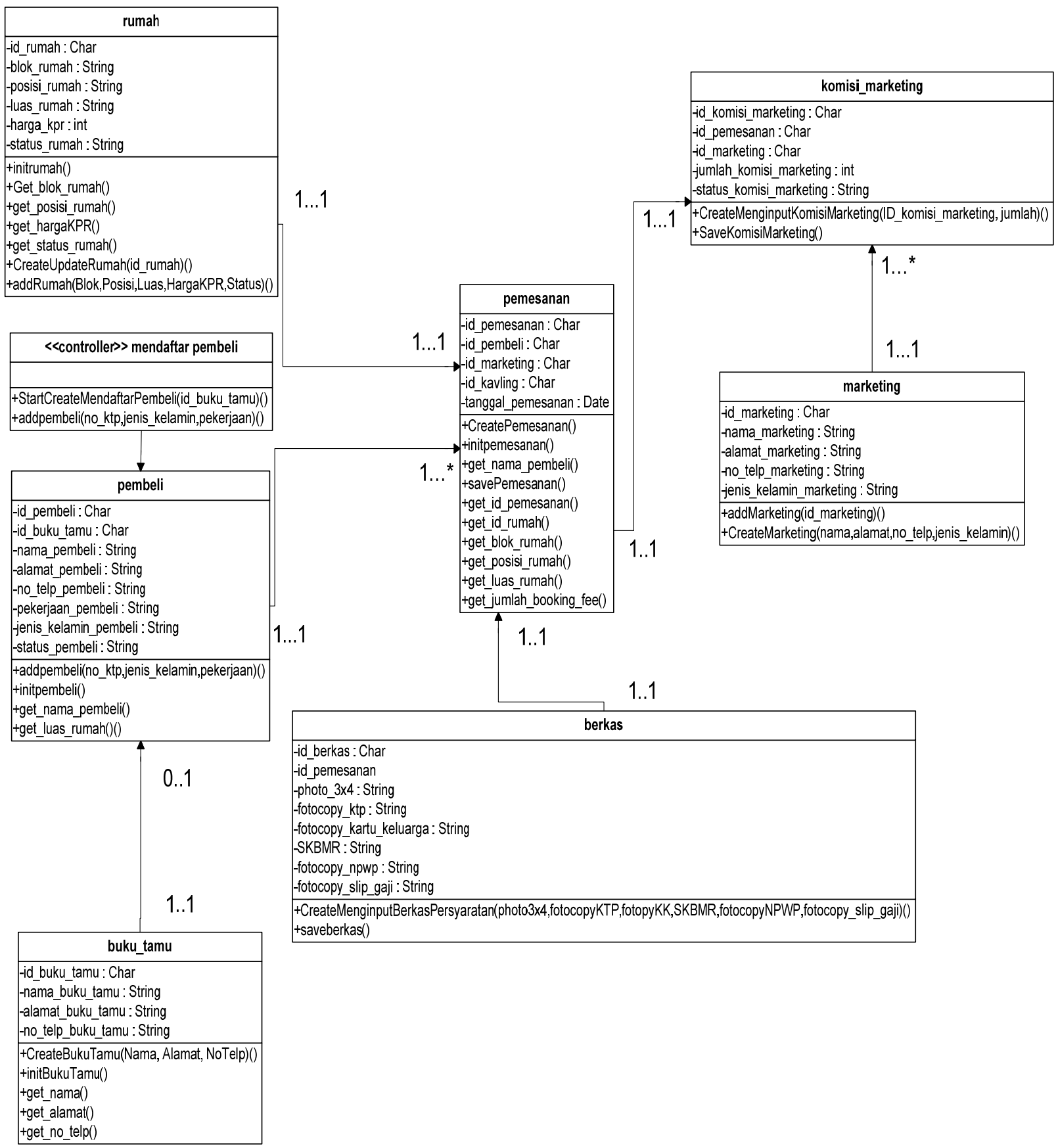

Gambar 3 Class Diagram

Di dalam merancang user interface perlu diperhatikan mengenai segi tata letak, konten estetika, user experience, dan konsistensi (Dennis, Wixom, \& Roth, 2013). Prinsip inilah yang digunakan sebagai acuan dalam merancang user interface untuk sistem informasi pemasaran pada CV. Rumah Vera. 
Berikut adalah beberapa tampilan user interface untuk sistem informasi yang diusulkan:

Form Pemesanan

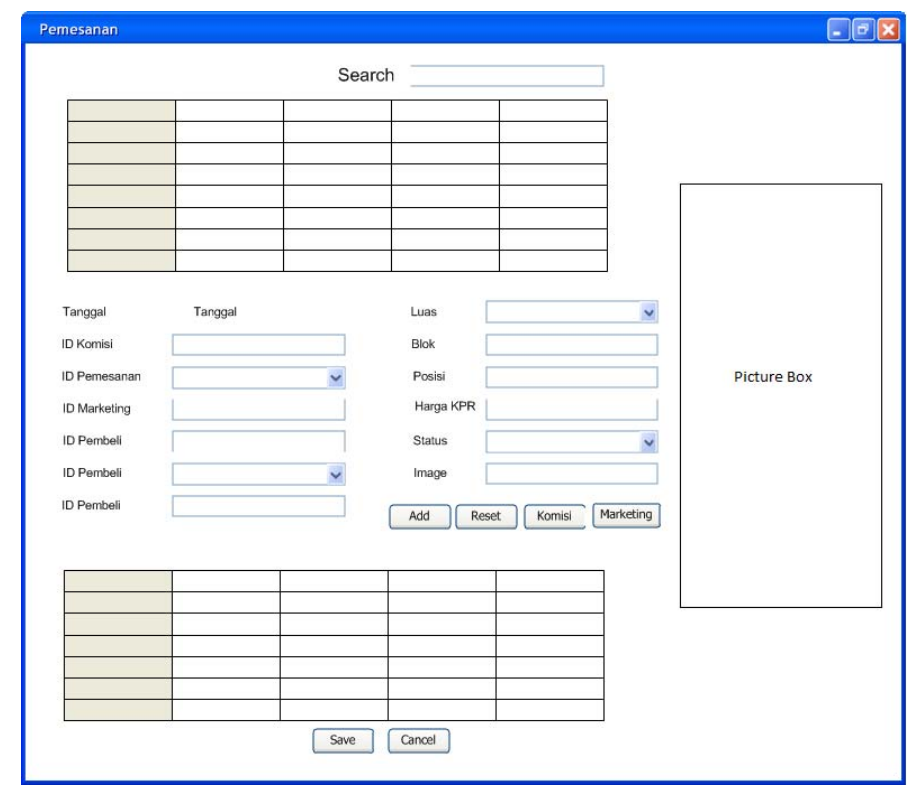

Gambar 4 User Interface Form Pemesanan

Form ini digunakan untuk melayani Pemesanan, ID pemesanan sudah ter-generate, ID pembeli dipilih dan akan muncul ID Pembeli yang sudah terdaftar, Nama pembeli sudah ter-generate sendiri ketika ID pembeli dipilih, ID rumah itu mengisi sendiri dengan melihat data grid view yang ada diatasnya. ID marketing dapat dipilih yang ada. Luas, blok, posisi, harga KPR, status, image sudah ter-generate apabila kita memasukan ID rumah. Klik Tombol "Add" untuk meng-input Data baru yang telah diisi untuk ID pemesanan. Klik Tombol "Reset" untuk mengosongkan data yang sudah ada dengan memasukan data baru. Klik Tombol "Komisi" untuk menghapus ID Rumah dan Data-datanya setelah di Search terlebih dahulu. Klik Tombol "Save" untuk Menyimpan Data yang ada di Form. Klik Tombol "Cancel” untuk Menginput Gambar Rumah yang akan di-input

\section{Form Komisi Marketing}

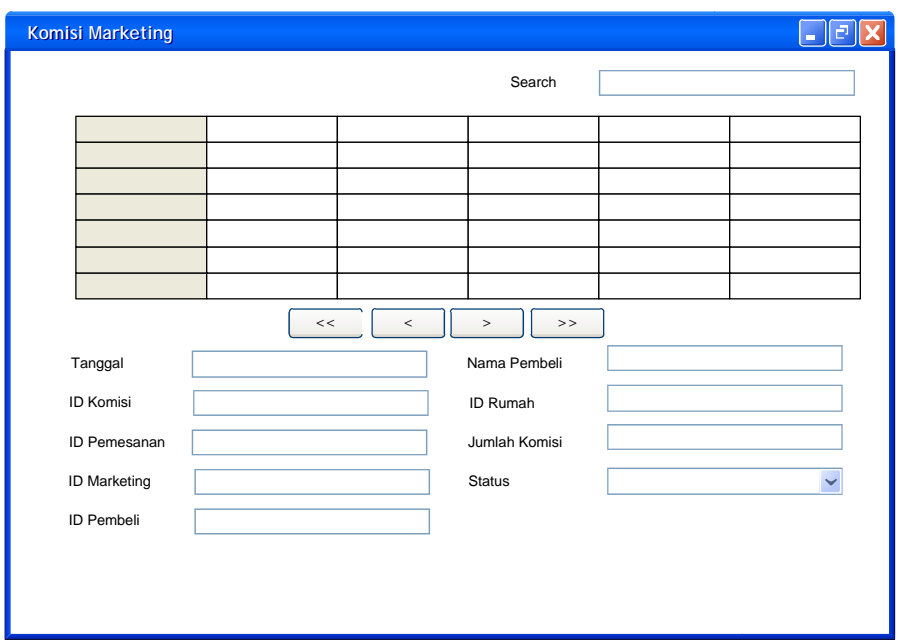

Gambar 5 User Interface Form Komisi marketing 
Form ini digunakan untuk memasukan komisi marketing, yang berisi ID komisi yaitu sudah ter-generate, ID Pemesanan, ID Marketing, ID Pembeli di-input sesuai yang ingin di-input, Nama Pembeli sudah ter-generate dr ID Pembeli, Jumlah komisi sudah diset Rp350.000,00. Status dapat dipilih hanya ada Sudah Terbayar dan Belum Terbayar.

Setelah admin melayani pemesanan, kuitansi ini dibuat oleh admin dan kemudian dicetak untuk diberikan untuk pembeli yang telah membayar booking fee. Berikut adalah tampilan output kuitansi dari sistem yang diusulkan :

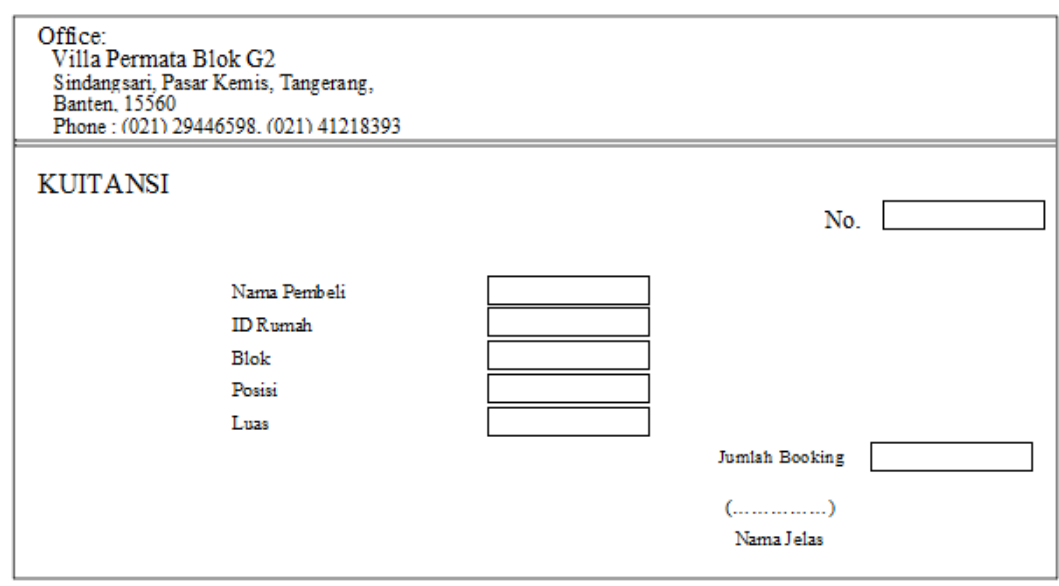

Gambar 6 System output design kuitansi

Sistem yang akan diimplementasikan memiliki integrity control yang berfungsi untuk memastikan bahwa data hanya dapat diakses oleh user yang memang menjadi tujuan dibuatnya sistem tersebut. Sistem memiliki input integrity control yang memastikan bahwa data yang dimasukkan adalah benar. Jika ada satu atau beberapa field yang kosong, maka data tidak akan dimasukkan ke dalam sistem dan sistem akan meminta user untuk mengisi field yang kosong.

Database memiliki integrity control seperti time stamp yang berguna untuk menyesuaikan waktu data dimasukkan sesuai dengan jam server. Output didesain agar sesuai dengan kebutuhan user dan memiliki integrity control seperti jam output dicetak. Sistem memiliki security control untuk menjaga agar data tidak diakses oleh yang tidak berkepentingan seperti metode akses sistem yang menggunakan username dan password. Dengan adanya verifikasi user ini maka diharapkan tidak ada data yang diakses oleh user yang tidak berkepentingan. Strategi implementasi sistem yang digunakan adalah cut-over, karena teknik ini memberhentikan sistem yang lama dan semua sistem menggunakan sistem yang baru.

\section{SIMPULAN}

Pada sistem informasi yang sedang berjalan masih terdapat kelemahan-kelemahan yang disebabkan oleh sistem manual, sehingga harus terus diperbaharui untuk dapat terus menunjang kegiatan operasional dari perusahaan. Dengan sistem informasi yang berbasis pada aplikasi yang terintegrasi dan menggunakan database, diharapkan proses bisnis yang berjalan menjadi lebih efektif dari segi waktu dan efisien dari segi biaya. Sistem manajemen marketing yang dirancang bertujuan untuk mempermudah perusahaan dalam pendaftaran calon marketing dan pembagian komisi marketing. Dengan adanya sistem informasi penjualan, yang menyimpan data-data pelanggan ke 
dalam database aplikasi akan mempermudah admin dalam meng-input calon pembeli dan mengecek proses penjualan yang ada. Dengan sistem yang dibuat sedemikian rupa, perusahaan mampu melakukan peninjauan dalam memajukan kegiatan penjualan. Training atau presentasi kepada karyawan lama maupun baru sangat dibutuhkan untuk mempercepat pemahaman karyawan terhadap sistem yang baru. Basis data harus sering di back-up secara berkala untuk menghindari hal-hal yang tidak diinginkan jika ada masalah di kemudian hari

\section{DAFTAR PUSTAKA}

Connolly, T., Begg, C. (2005). Database System: A Practical Approach to Design, Implementation, and Management. ( $4^{\text {th }}$ Edition). Harlow, England: Addison Wesley

Dennis, A., Wixom, BH., Roth, RM. (2013). System Analysis and Design. (5 ${ }^{\text {th }}$ Edition). Singapore.

Forster, F., Brocco, M. (2008) Understanding Creativity-Technique Based Problem Solving Processes. In Lovrek, I., Howlett, R.J., Jain, L.C. International Conference on Knowledge-Based Intelligent Information and Engineering Systems, 5178

Kotler, P. (2004). Manajemen Pemasaran. Edisi Millenium. PT. Prenhallinda, Jakarta . (2006). Marketing Management. (12 ${ }^{\text {th }}$ Edition). Prentice Hall.

Markus, M. L., Majchrzak, A., Gasser, L. (2006) A Design Theory for Systems that Support Emergent Knowledge Processes. MIS Quarterly, 26, 179-212.

Satzinger, J W., Jackson, R.B., Burd, S.D. (2005). Object-Oriented Analysis and Design with Unified Process. USA: Cengage Learning.

. (2012). System Analysis and Design in A Changing World. USA: Cengage Learning. 